\title{
Stability of Mandibular Irregularity Index With and Without PAO0: A Review
}

\author{
Laith Makki and Donald J Ferguson* \\ European University College, Dubai Healthcare City, UAE
}

Submission: March 03, 2016; Published: April 27, 2017

*Corresponding author: Donald J Ferguson, European University College, Dubai Healthcare City, UAE, Mobile: +971 501492375 ; Tel: +971 4362

4788, Fax: +971 4362 4793; Email: fergusonloud@gmail.com

\begin{abstract}
Periodontally accelerated osteogenic orthodontics (PAOO) is an accelerated tooth movement technique resulting in enhanced stability of treatment outcomes. Mandibular irregularity index was recently demonstrated to be significantly more stable at 10 -years post treatment, and the purpose of this review article was to summarize current literature results. Under experimental conditions with and without PAO0, irregularity index at 5 -years post treatment changed $0.4 \mathrm{~mm}$ versus $2.8 \mathrm{~mm}$, and at 10 -years, $0.9 \mathrm{~mm}$ versus $2.4 \mathrm{~mm}(\mathrm{P}=.000)$. The 10 -year PAO0 results were then compared to mandibular irregularity index changes from a comprehensive review of the scholarly literature; PA00 demonstrated $54 \%$ less change than patients orthodontically treated without PAOO and $40 \%$ less change than untreated subjects. While the 10 -year PAO0 change of 0.9 $\mathrm{mm}$ was more than twice the amount of change $(0.41 \mathrm{~mm})$ compared to fixed canine-to-canine retention patients, it is the only active treatment technique that significantly reduces mandibular anterior segment recording of post orthodontic outcomes.
\end{abstract}

Keywords: Irregularity index, PA00, Stability, Mandibular crowding

\section{Introduction}

Long-term stability after orthodontic treatment is highly desirable, especially alignment of the mandibular anterior dentition as might be quantified by the irregularity index. Post orthodontic treatment stability is a vexing problem, and without permanent fixed retention, this issue has been a problem without a solution until recently. In 2014, long term stability of the mandibular anterior segment was shown to be affected by alveolar corticotomy and augmentation bone grafting (PAOO) [1].

Mandibular incisor crowding increases over time and there are no dependable predictors $[2,3]$. These two observation is so prevalent in refereed orthodontic literature they are regarded a consensus tenets. The amount of crowding change varies so greatly that increased crowding cannot be anticipated; this observation applies to untreated individuals [4-6]. Eighteen Swedish dentists with intact dentitions and no history of orthodontic or prosthodontic treatment were followed for 40 years from ages 20 to 60 ; the authors found a significant increase in Little's irregularity index (1.0 mm; $P=0.01$ ) [7]. Fifteen untreated adolescents and 18 untreated adults were observed over a span of about three decades and the rate of mandibular irregularity index increase was significantly greater in adolescents than in adults [8].

Mandibular anterior crowding increases are also well documented in post ortho dontically treated samples. Richardson
[9] reported increases in irregularity index averaging $2.56 \mathrm{~mm}$ from 18 previous investigations $(n=1,117)$ of extraction and nonextraction patients. Shah [10] reported mean post-treatment irregularity changes ranging from 0.6 to $4.88 \mathrm{~mm}$ after reviewing 29 studies ( $\mathrm{n}=1683)$.

Little [11] used mandibular irregularity index to quantify the percentage of successful orthodontic treatment outcomes in the absence of permanent bonded retention. He designated an irregularity index score of $<3.5 \mathrm{~mm}$ as representing clinically acceptable by Little et al. $[12,13]$; he demonstrated in orthodontically treated premolar extraction cases a success rate of $30 \%$ at 10 years post retention and only $10 \%$ at 20 years post retention.

Long term $20+$ years of mandibular anterior segment stability after orthodontics has been demonstrated by Booth et al. [14] by placement of fixed permanent canine-to-canine retention. Fixed, uninterrupted retention is the only treatment strategy that assures irregularity index will not exceed $3.5 \mathrm{~mm}$, but it is a post treatment strategy.

Until recently, no active orthodontic treatment strategy has been shown to be effective at minimizing mandibular anterior recrowding. Makki et al. [15] recently reported mandibular irregularity index stability in PAOO subjects with incremental 
increases of $0.4 \mathrm{~mm}$ at 5 -years and $0.9 \mathrm{~mm}$ at 10 -years. These small changes were in sharp contrast to non-PAOO groups at 5-years (2.8 mm, $\mathrm{P}=.000)$ and 10 -years $(2.4 \mathrm{~mm}, \mathrm{P}=.000)$. None of the retention schemes in this study included long term fixed permanent retention.

These stunning results prompted a comprehensive literature review study by Ferguson et al. [16] comparing the PAOO irregularity index results 15 with both orthodontically treated and untreated long 10-year outcomes. Treated outcomes were represented in the scholarly literature by 3181 patients in 53 publications; untreated subjects were represented by 1069 individuals in 23 articles. As described previously15, irregularity index in 22 PAOO patients changed $0.9 \mathrm{~mm}$ in 10 -years while non-PAOO treated patients changed more than twice as much $(1.96 \mathrm{~mm})$ and untreated subjects changed $1.49 \mathrm{~mm}$. Also reviewed in the article were irregularity index changes for fixed canine-tocanine retainer patients; there were 330 patients represented in four publications and average irregularity index change was only $0.41 \mathrm{~mm}$. After comparing augmented corticotomy with the scholarly literature, it was concluded that PAOO is the only active orthodontic treatment strategy that results in post treatment mandibular anterior irregularity index stability [16].

\section{Discussion}

Why are augmented corticotomy results so stable? This is a reasonable question given the fact that post orthodontic treatment stability is so important to the profession. No other active treatment technique or procedure leads to mandibular anterior segment stability, so what is it about PAOO that distinguishes it from other techniques? PAOO includes minor surgery with a full thickness periosteal flap and intentionally scarring the alveolar cortex with a high speed surgical bur under copious irrigation [17]. The surgical trauma initiates an inflammatory healing response called regional acceleratory phenomena or RAP which increases tissue turnover [18]. Authors of the PAOO technique believe this increase in tissue turnover may be partly responsible for the loss of tissue memory [19]. Moreover, augmentation bone grafting increases the cortical thickness of the alveolar bone surrounding the dentition, and it is believed that increased cortical thickness reduces the risk of post orthodontic treatment recrowding $[20,21]$.

Whether or not increased tissue turnover and/or increased cortical thickness reduce the risk of mandibular anterior segment instability is only speculation at this time. But circumstantial evidence suggests there is merit in believing these two factors enhance stability. The human body exists in an environment of mechanical stress (gravity, locomotion, etc.) Tissues maintain a certain level of tension, called prestress or tensional integrity, that may differ somewhat from individual to individual depending upon a host of factors including age, level of daily activity (athletic versus sedate), health (well versus ill), etc. These forces create a prestressed structural network that can sustain itself and, at the same time, can spontaneously accommodate perturbations $[22,23]$. The tensional readiness of body resets itself after the invasive PAOO surgery and the local tissues likely are more reticent to change back to pre-surgery, prestress levels. Part of that reticence is likely due to the new tissue structure built from the local tissue turnover with different tensional integrity.

Augmentation bone grafting increases cortical bone thickness [24], and thin cortices have been reported as a risk factor in mandibular anterior segment recrowding [20,21]. In the absence of fixed retention, Rothe et al. [20] compared 10-year postorthodontic samples of minimal $(3.5 \mathrm{~mm})$ and high $(6 \mathrm{~mm})$ irregularity index. The authors measured mandibular inferior border cortices and, by a priori application to the alveolus surrounding the mandibular anterior dentition, concluded that patients with thinner mandibular cortices were at increased risk for mandibular anterior dental relapse. This finding was confirmed two years later in another study by the same investigative group [21].

\section{Conclusion}

One of the instability tenets of the mandibular dental arch is that irregularity index in the permanent dentition will increase with time. This has been shown to be true in the untreated and following orthodontic treatment, extraction or non-extraction, irrespective of gender and/or culture-ethnicity. The only "proven" way to prevent unwanted recrowding of the mandibular anterior segment after treatment is fixed retention. The only way to prevent mandibular anterior recrowding with active orthodontic treatment is by way of augmented corticotomy (PAO0).

\section{References}

1. Ferguson DJ, Makki L, Stapelberg R, Wilcko MT, Wilcko WM (2014) Stability of the mandibular dental arch following periodontally accelerated osteogenic orthodontics therapy: Preliminary studies. Semin Orthod 20(3): 239-246.

2. Little RM (1990) Stability and relapse of dental arch alignment. Br J Orthod 17(3): 235-241.

3. Buschang PH (2014) Class Imalocclusions - The development and etiology of mandibular malalignments. Semin Orthod 20(1): 3-15.

4. Myser SA, Campell PM, Boley J, Buschang PH (2013) Long-term stability: Postretention changes of the mandibular anterior teeth. Am J Orthod Dentofac Orthop 144(3): 420-429.

5. Sinclair PM, Little RM (1983) Maturation of untreated normal occlusions. Am J Orthod 83(2): 114-123.

6. Tibana RHW, Palagi LM, Miguel JAM (2004) Changes in dental arch measurements of young adults with normal occlusion-A longitudinal study. Angle Orthod 74(5): 618-623.

7. Tsiopas N, Nilner M, Bondemark L, Bjerklin K (2013) A 40 years followup of dental arch dimensions and incisor irregularity in adults. Eur J Orthod 35(2): 230-235.

8. Eslambolchi S, Woodside DG, Rossouw PE (2008) A descriptive study of mandibular incisor alignment in untreated subjects. Am J Orthod Dentofacial Orthop 133(3): 343-353.

9. Richardson ME, Gormley JS (1998) Lower arch crowding in the third decade. Eur J Orthod 20(5): 597-607.

10. Shah AA (2003) Postretention changes in mandibular crowding: a review of the literature. Am J Orthod Dentofac Orthop 124(3): 298-308. 
11. Little RM (1999) Stability and relapse of mandibular anterior alignment: University of Washington studies. Semin Orthod 5(3): 191 204

12. Little RM, Riedel RA, Artun J (1988) An evaluation of changes in mandibular anterior alignment from 10 to 20 years postretention. Am J Orthod Dentofacial Orthop 93(5): 423-428.

13. Little R, Wallen TR, Riedel RA (1981) Stability and relapse of mandibular anterior alignment-first premolar extraction cases treated by traditional edgewise orthodontics. AJO 80(4): 349-365.

14. Booth FA, Edelman JM, Proffit WR (2008) Twenty-year follow-up of patients with permanently bonded mandibular canine-to-canine retainers. Am J Orthod Dentofacial Orthop 133(1): 70-76.

15. Makki L, Ferguson DJ, Wilcko MT, Wilcko WM, Bjerklin K, et al. (2015) Mandibular irregularity index stability following alveolar corticotomy and grafting: A 10 year preliminary study. Angle Orthod 85(5): 743749

16. Ferguson DJ, Makki L, Wilcko MT, Wilcko WM (2017) Instability of the mandibular dental arch? Look again! Semin Orthod YSOD0492, DOI 10.1053/j.sodo.2016.12.006.

17. Murphy KG, Wilcko TW, Wilcko WM Ferguson DJ (2009) Periodontal accelerated osteogenic orthodontics: A description of the surgical technique, JOMS 67: 2160-2166.
18. Frost HM (1983) The regional accelerated phenomenon: a review. Henry Ford Hosp Med J 31(1): 3-9.

19. Wilcko WM, Wilcko MT, Bouquot JE, Ferguson DJ (2001) Rapid Orthodontics with Alveolar Reshaping: Two Case Reports of Decrowding. Internat J Perio \& Restor Dent 21 (1): 9-19.

20. Rothe LE, Bollen A-M, Little RM, Herring SW, Chaison JB, et al. (2006) Trabecular and cortical bone as risk factors for orthodontic relapse. Am J Orthod Dentofacial Orthop 130(4): 476-484.

21. Chaison JB, Chen CS, Herring SW, Bollen A-M (2010) Bone volume, tooth volume, and incisor relapse: a 3-dimensional analysis of orthodontic stability. Am J Orthod Dentofacial Orthop 138(6): 778-786.

22. Ingber DE (2008) Tensegrity-based mechanosensing from macro to micro. Prog Biophys Mol Biol 97(2-3): 163-179.

23. Humphreys JD Dufresne ER Schwartz MA (2014) Mechanotransduction and extracellular matrix homeostasis. Nat Rev Mol Cell Biol 15(12): 802-812.

24. Twaddle BA, Ferguson DJ, Wilcko WM, Wilcko MT (2002) Dentoalveolar bone density changes following accelerated orthodontics. J Dent Res 80: 301.

\section{Your next submission with Juniper Publishers will reach you the below assets}

- Quality Editorial service

- Swift Peer Review

- Reprints availability

- E-prints Service

- Manuscript Podcast for convenient understanding

- Global attainment for your research

- Manuscript accessibility in different formats

( Pdf, E-pub, Full Text, Audio)

- Unceasing customer service

Track the below URL for one-step submission

https://juniperpublishers.com/online-submission.php 